\title{
RANCANG TUGAL PUPUK JAGUNG TIPE VERTICAL
}

\author{
Made Putra Widana ${ }^{1}$, Evi Sunarti Antu' ${ }^{2}$, Romi Djafar ${ }^{3)}$ \\ ${ }^{1}$ Mahasiswa Program Studi Mesin dan Peralatan Pertanian, Politeknik Gorontalo \\ ${ }^{2,3}$ Dosen Program Studi Mesin dan Peralatan Pertanian, Politeknik Gorontalo \\ Email: widanaputra025@gmail.com
}

\begin{abstract}
ABSTRAK
Alat tugal pupuk adalah alat yang digunakan untuk membagi/menabur pupuk. Untuk saat ini model pemupukan jagung paling banyak masih dilakukan dengan cara manaual. Kondisi ini sangat memberatkan bagi para petani karena disamping proses pemupukan yang lambat juga harus membutuhkan tenaga manusia yang banyak untuk menyelesaikan pekerjaan tersebut. Disamping tenaga yang banyak, efek lainya seperti petani sangat kelelahan bekerja sebab badan terus membungkuk selama proses pemupukan. Pada penelitian ini bertujuan untuk mendesain alat tugal pupuk tipe vertical pressure yang tepat guna hingga mengetahui cara kerja alat dan mengetahui hasil penaburan pupuk sesuai dengan level takaran. Adapun metode pada penelitian ini yaitu dilakukan tiga runing pengujian dengan menyetel level takaran kemudian dihitung berapa jarak yang ditempuh untuk waktu tertentu. Berdasarkan hail pengujian diperoleh bahwa runing satu dengan jumlah pupuk 15.7 gram memperoleh jarak 48 $\mathrm{m}$ dengan waktu 6.12 menit dengan jumlah total pupuk $5 \mathrm{~kg}$. Untuk runing dua dengan jumlah pupuk 30 gram memperoleh jarak 36 m membutuhkan waktu 4.59 menit dengan total pupuk yang sama. Sedangkan untuk raning tiga dengan jumlah pupuk 90 gram memperoleh jarak 23 m dengan waktu 2.15 menit dengan total pupuk yang sama. Alat ini sangat efektif digunakan oleh petani.
\end{abstract}

Kata Kunci: Tugal pupuk, menggunakan level takaran

\section{ABSTRACT}

Tugal fertilizer is a tool used to divide / sow fertilizer. For the time being, the most widely fertilized corn model is done in a manaual way. This condition is very burdensome for farmers because in addition to the slow fertilization process also must require a lot of human labor to complete the work. Besides a lot of energy, other effects such as farmers are very tired working because the body continues to bend during the fertilization process. In this study aims to design a vertical pressure type fertilizer tool that is appropriate to find out how the tool works and determine the results offertilizer sowing according to dose level. The method in this research is to do three test runings by setting the dose level and then calculating the distance traveled for a certain time. Based on the results of the test, it was obtained that runing one with the amount of fertilizer 15.7 grams obtained a distance of $48 \mathrm{~m}$ with a time of 6.12 minutes with a total amount of fertilizer of $5 \mathrm{~kg}$. For runing two with 30 grams of fertilizer, getting a distance of $36 \mathrm{~m}$ takes 4.59 minutes with the same total fertilizer. Whereas for raning three with the amount of 90 gram fertilizer, it gets a distance of $23 \mathrm{~m}$ with a time of 2.15 minutes with the same total fertilizer. This tool is very effectively used by farmers.

Keywords : tugal fertilizer, using dose lev 


\section{PENDAHULUAN}

Indonesia merupakan negara agraris terbesar di dunia yang bersumber dari hasil pertanian dan perkebunan. Salah satu sumber pertanian adalah tanaman jagung yang merupakan komoditas unggulan untuk menambah pendapatan masyarakat khususnya di Provinsi Gorontalo. Pertumbuhan tanaman jagung dapat dipengaruhi oleh beberapa faktor salah satunya proses pemupukan. Pemupukan merupakan salah satu kegiatan yang sangat penting dalam budidaya jagung. Untuk mendapatkan hasil produksi maksimal maka diperlukan pemupukan yang efektif. Ketika pemberian dosis pupuk semakin banyak dimasukkan kedalam tanah maka hasil tanaman jagung akan semakin meningkat. (Isrun, 2006)

Saat ini model pemupukan jagung paling banyak masih dilakukan dengan cara manaual. Kondisi ini sangat memberatkan bagi para petani karena disamping proses pemupukan yang lambat juga harus membutuhkan tenaga manusia yang banyak untuk menyelesaikan pekerjaan tersebut. Disamping tenaga yang banyak, efek lainya seperti petani sangat kelelahan bekerja sebab badan terus membungkuk selama proses pemupukan.

Oleh karena itu perlu dicari upaya yang telah dilakukan untuk menyelesaikan berbagai persoalan yang dihadapi petani khususnya solusi untuk pemupukan jagung berupa peralatan alat pemupuk jagung yang dioperasikan semi manual. Tentu saja sistem alat pupuk tersebut dirasa belum efisien karena jumlah dosis pupuk yang keluar dari outletnya belum dapat dikontrol secara sempurna. Jumlah pupuk yang keluar hanya dapat dikendalikan berdasarkan perkiraan saja. Maka dari itu perlu adanya inovasi dari alat yang sudah ada yaitu proses pengoperasiaanya yang dioperasikan dengan mudah serta jumlah pupuk sesuai dengan dosis yang diingikan.

Rancang bangun alat pemupuk jagung sistem dorong, Agustiawan dkk, (2019) berhasil melakukan penelitian berupa membandingkan mekanisme kerja alat pupuk tipe dorong dengan model pemupukan sistem manual. Berdasarkan hasil penelitian dapat disimpulkan bahwa alat ini paling cocok digunakan untuk kondisi lahan yang pemupukan dilakukan sebelum penanaman jagung.

Syafriandi dan Andriani (2015) telah melakukan pengembangan berbagai mekanisme penjatah untuk melakukan penjatahan yang konsisten dan seragam. Namun kendala dari alat yang dibuat berupa laju kecepatan motor penjatah belum setara dengan kapasitas.

Pada penelitian ini akan dirancang alat tugal pupuk yang memiliki katup penakar pupuk sehingga jumlah pupuk yang keluar sesuai dengan jumblah dosis yang diharapkan serta mempermudah petani dalam proses pemupukan sehingga tidak lagi membutuhkan tenaga dan waktu yang banyak.

\section{METODE PENELITIAN \\ Waktu Dan Tempat Penelitian}

Waktu pelaksanaan penelitian dimulai sesuai kegiatn penelitian yang akan ditentukan sampai dengan selesai selama bulan April-Juni. Pembuatan alat dilaksanakan di Laboraturium Mesin Umum Program studi Mesin dan Peralatan Pertanian Politeknik Gorontalo. Pegujian alat dilakukan di bidang pengujian

\section{Diagram Alir}

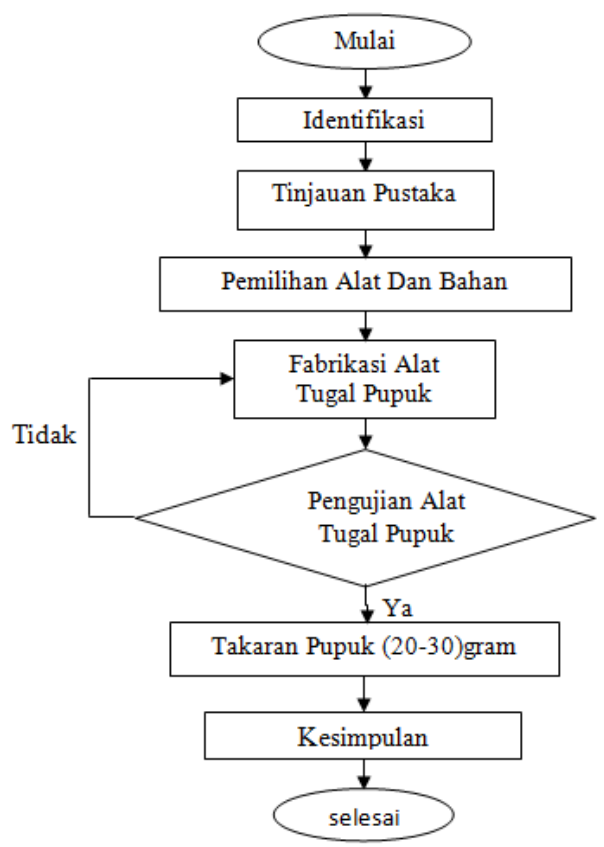

Gambar 1 Diagram Alir Penelitian

Dalam susunan diagram alir ada beberapa tahap yang perlu kita ketahui proses penelitian fabrikasi dan pengujian alat tugal pupuk. Yaitu dengan mengetahui skema pengujian bahan yang akan di tabur dengan kapasitas alat penabur.

\section{Alat dan bahan}

Pemilihan bahan sangatlah penting dilakukan dalam pembuatan alat bertujuan agar mendapatkan bahan yang sesuai dengan harapan dan alat yang akan dibuat. Pemilihan galon air mineral sebagai wadah pupuk dilakukan selain dengan bentuk yang diharapkan galon air mineral dapat menampung pupuk lebih banyak. Pemilihan pipa pvc sebagai tugal karena setruktur bahannya yang 
kuat dan tidak mudah patah hal itu membuat pipa pvc sangat cocok dijadikan sebagai tugal.

Bentuk dan kriteria untuk dijadikan bahan dalam pembuatan tugal pupuk harus meliputi sebagai berikut:

- Design (bentuk) bahan.

- Ukuran panjang x diameter.

- Mempunyai struktur yang kuat dan tidak mudah karat.

\section{Kualitas bahan material dasarnya.}

Pemilihan bahan material dalam pembuatan tugal pupuk yang keliru (tidak sesuai) akan mengakibatkan banyak permasalahan yang ditimbulkan atas kekeliruan.

\section{Alat yang digunakan}

- Geregaji besi : Digunakan untuk memotong

- Mistar baja : Digunakan untuk mengukur bahan yang akan di pakai

- Palu : Digunakan untuk memaku memperbaiki suatu benda

- Bor tangan : Digunakan untuk mengebor suatu benda kerja

- Sepidol : Digunakan untuk memberi warna pada garis ukuran

\section{Bahan yang digunakan \\ - Galon air mineral \\ - Pipa pvc \\ - Sambungan pipa \\ - Selang \\ - Per (pegas) \\ - Penutup pipa}

\section{HASIL DAN PEMBAHASAN}

\section{Perinsip Kerja Alat}

Sumber tenaga utama yang digunakan adalah tenaga manusia. Pupuk yang dimasukan ke wadah pupuk akan bergerak menuju tugal selanjutnya pupuk akan berhenti pada ujung tugal. Kemudian tugal di tekan ke arah tanah sehingga mengakibatkan ujung tugal yang telah diberi lubang terbuka, setelah lubang terbuka maka pupuk akan keluar melalui lubang.

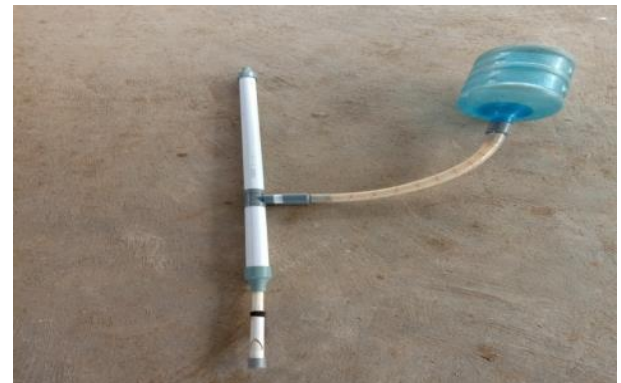

Gambar 2 Hasil Rancang Alat Tugal Pupuk

Penyetel level takaran dilakukan dengan cara membuka pipa ujung tugal yang berukuran $3 / 4$ lalu lakukan penyetelan level dengan menekan level takaran ke atas untuk memperkecil level atau menekan kebawah untuk memperbesar level sehingga tepat di level takaran yang akan digunakan.

\section{Kapasitas Efektif Alat}

Kapasitas efektif alat di peroleh dengan melakukan proses pemupukan pada lahan sebanyak tiga kali ulangan,kemudiaan dihitung kapasitas efektif rata-rata alat. Kapasitas efektif suatu alat menunjukan produktivitas alat selama pengoprasian tiap satuan waktu. Dalam hal ini,kapasitas efektif alat diukur dengan membagi luas lahan (m) terhadap waktu yang dibutuhkan selama pengoprasian alat dengan jumblah pupuk yang telah ditentukan. Kapasitas alat dilakukan dengan menghitung banyaknya hasil penaburan $(\mathrm{kg})$ tiap satuan waktu yang dibutuhkan selama pengoprasian (menit).

Pada penelitian ini dilakukan tiga kali ulangan pengujian alat dengan memperhatikan jarak pemupukan yaitu $40 \mathrm{~cm}$ untuk jarak penanaman jagung.

\section{Keseragaman Hasil Penaburan}

hasil penaburan dari setiap level takaran dapat di kelompokan ke dalam jumlah taburan 15.7gram, 30 gram dan 90gram. Ukuran yang sering di pakai adalah 30gram sesuai dengan kebutuhan tanaman.

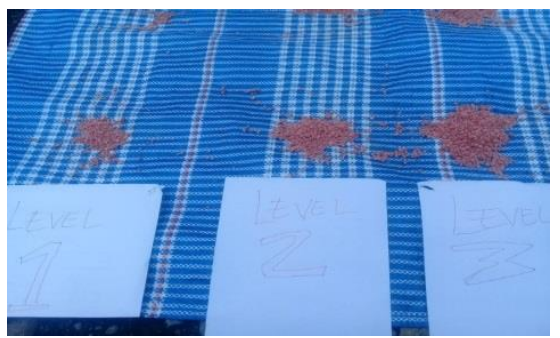

Gambar 3 Hasil Penaburan level 1, level 2, dan level 3 
Pada gambar penaburan terdapat 3 macan ukuran yang berbeda yaitu 15.7 gram, 30 gram, dan 90 gram. Hasil yang berbeda didapatkan dari level takaran yang berbeda yaitu level 1 , level 2 , dan level 3.

\section{Variabel Hasil Penaburan}

Pengujian hasil penaburan pupuk menggunakan alat tugal pupuk menggunakan tiga level takaran dengan berat pupuk masing-masing 5 $\mathrm{kg}$ mendapatkan hasil yang berfariasi seperti yang ditunjukan pada tabel dibawah:

Tabel 1 Jumlah pupuk terhadap waktu

\begin{tabular}{|c|c|c|c|c|c|}
\hline No & $\begin{array}{c}\text { Tahapan } \\
\text { Ujicoba }\end{array}$ & $\begin{array}{c}\text { Besar lubang } \\
\text { Level tekanan } \\
(\mathrm{cm})\end{array}$ & $\begin{array}{c}\text { jumlah } \\
\text { Pupuk } \\
\text { (gram) }\end{array}$ & $\begin{array}{c}\text { Waktu } \\
(\text { detik) }\end{array}$ & $\begin{array}{c}\text { panjang } \\
\text { area } \\
(\mathrm{cm})\end{array}$ \\
\hline 1 & Runing 1 & 1 & 15.7 & 3 & 40 \\
\hline 2 & Runing 2 & 2 & 30 & 3 & 40 \\
\hline 3 & Runing 3 & 4 & 90 & 3 & 40 \\
\hline
\end{tabular}

Pada pengujian ini menggunakan tiga tahap ujicoba yaitu runing 1 , runing 2 , dan runing 3 . Pada pengujian runing 1 menggunakan level tekanan $1 \mathrm{~cm}$ didapatkan hasil jumlah pupuk sebanyak 15.7 gram dengan waktu tekan 3 detik dan panjang area $40 \mathrm{~cm}$. Kemudian pada runing 2 menggunakan level tekanan $2 \mathrm{~cm}$ didapakan hasil jumblah pupuk 30 gram dengan waktu tekan 3 detik dan luas area 40 $\mathrm{cm}$. Pada runing 3 menggunakan level tekanan $4 \mathrm{~cm}$ didapat hasil jumlah pupuk sebanyak 90 gram dengan waktu dan luas area yang sama.

Berdasarkan pengujian bahwa semakin besar lubang pada level tekanan $(\mathrm{cm})$ maka semakin banyak jumlah pupuk yang keluar (gram) begitu juga dengan sebaliknya.

Menurut Subekti (2008) bahwa, pemberian dosis pupuk yang tepat perlu dilakukan untuk menyeimbangkan hara sehingga tanaman dapat tumbuh dan berkembang dengan baik. Dosis pupuk yang paling banyak di gunakan oleh petani yaitu 30 gram pada setiap pohon. Hal ini di karenakan dosis NPK 30 gram dapat meningkatkan pertumbuhan dan hasil jagung sehingga direkomendasikan untuk digunakan.

Tabel 2. Jumlah pupuk terhadap level posisi tekanan

\begin{tabular}{|c|c|c|c|c|c|}
\hline No & $\begin{array}{c}\text { Massa pupuk } \\
\text { (kg) }\end{array}$ & $\begin{array}{c}\text { Besar lubang } \\
\text { level tekanan } \\
\text { (cm) }\end{array}$ & $\begin{array}{c}\text { Jumblah } \\
\text { pupuk } \\
\text { (gram) }\end{array}$ & $\begin{array}{c}\text { Panjang } \\
\text { Area } \\
\text { (meter) }\end{array}$ & $\begin{array}{c}\text { Waktu } \\
\text { (menit) }\end{array}$ \\
\hline 1 & 5 & 1 & 15.7 & 48 & 6.12 \\
\hline 2 & 5 & 2 & 30 & 36 & 4.59 \\
\hline 3 & 5 & 4 & 90 & 23 & 2.15 \\
\hline
\end{tabular}

Hasil penaburan pupuk yang didapatkan dari massa pupuk $5 \mathrm{~kg}$ dengan pengujian sebanyak 3 kali menggunakan alat tugal pupuk yaitu pengujian pertama, kedua, dan ketiga mendapatkan hasil yang berfarisi. Pengujian pertama menggunakan level Tekanan $1 \mathrm{~cm}$ dengan massa pupuk $5 \mathrm{~kg}$ dapat memupuk dengan panjang area $48 \mathrm{~m}$ membutuhkan waktu selama 6.12 menit. Pengujian kedu dilakukan dengan menggunakan level takaran $2 \mathrm{~cm}$ dengan massa pupuk yang sama dapat memupuk dengan panjang area $36 \mathrm{~m}$ dengan waktu selama 4.59 menit. Pada pengujian ketiga menggunakan level takaran $4 \mathrm{~cm}$ dengan masa pupuk yang sama dapat memupuk dengan panjang area yang berkurang yaitu $23 \mathrm{~m}$ menggunakan waktu selama 2.15 menit.

Dengan ini di simpulkan bahwa semakin besar lubang pada level tekan $(\mathrm{cm})$ maka semakin berkurang panjang area dan waktu yang dibutuhkan dalam proses pemupukan atau semakin besar lubang pada level tekan $(\mathrm{cm})$ maka semakin banyak jumlah pupuk yang keluar begitu juga dengan sebaliknya.

\section{Kesimpulan}

Berdasarkan hasil pengujian alat maka di dapat beberapa kesimpulan sebagai berikut:

- Alat Pemupuk dapat di atur sesuai takaran pupuk yang di inginkan yaitu level 1. 2 dan 3 .

- Jumlah Dosis pemupukan yang terbaik adalah 30 gram.

- Level tekanan alat pemupuk yang dapat digunakan adalah level 2 yang berkolerasi dengan kebiasaan digunakan Petani

\section{DAFTAR PUSTAKA}

Isrun. (2006). Pengaruh Dosis pupuk P dan Jenis Pupuk Kandang Terhadap Beberapa Sifat Kimia Tanah, Serapan P Dan Hasil Jagung Manis (Zea mays saccharata Sturt) Pada Inceptisol Jatinagor. J. Agrisains 7(1):9-17.

Agustiawan1), Jamaluddin P2)Muh. Rais3), Rancang Bangun Alat Pemupuk Jagung Tipe Dorong Designing A Corn Fertilizer Tool Type Push, urnal Pendidikan Teknologi Pertanian Volume 4 Oktober Suplemen (2018) : S258S264

Syafriandi dan Andriani, (2015). Rancang Bangun dan Pengujian Alat Pejatah (metering device) Tipe Edge Cell Untuk Penyaluran Pupuk Butiran Urea, TSP dan KCL. Rona Teknik Pertanian 8(1), 41-50.

Enwall, Karin, (2005). "Activity and Ccomposition of the Denitrifying Bacterial Community Respond Differently To Long-Term Fertilization". Applied and Environmental Microbiology. American society for Microbiology.

Birkhofera, Klaus (2008). "Long-Term Organic Farming Foster Below and Aboveground Biota: Implications for soil quality, 
Biological control and Productivity". Soil Biologi and Biochemistry.

Pimentel, David, (2005). "Efironmental, Energetic, and Economic Comparisons of Organic and Conventional Farming System”. BioScience. Hlm. Ol. 55, no. 7, Peges 573-582.

Daywin, (2008). Mesin Budidaya Pertanian di Lahan Kering. Graha Ilmu, Yogyakarta.

Subekti NA, Syafiruddin, Evendi R, Sunarti S. 2008. Morfologi tanaman dan fase pertumbuhan jagung Sulawesi Selatan. Balai penelitian tanaman serealia Sulawesi Selatan. URL : http//balitsereallitbang.deptan.co.id.

"NPK Ratios of Common Organic materials". Diakses 2 januari 2020 pukul 19:20 https://id.m.wikipedia.org/wiki/pupuk. diakses 2 januari 2020 pukul 20:31

http://mesinpertanian saam.blogspot.com/2015/alatpemupuk-manual-manual-

knapsack.html?m=1. diakses 3 januari 2020 pukul 09:15

https://kabartani.com/cara-sederhana-membuat-alatpenabur-pupuk-dari-pipa-paralon-pvc.httml. diakses 3 januari 2020 pukul 11:45 . 